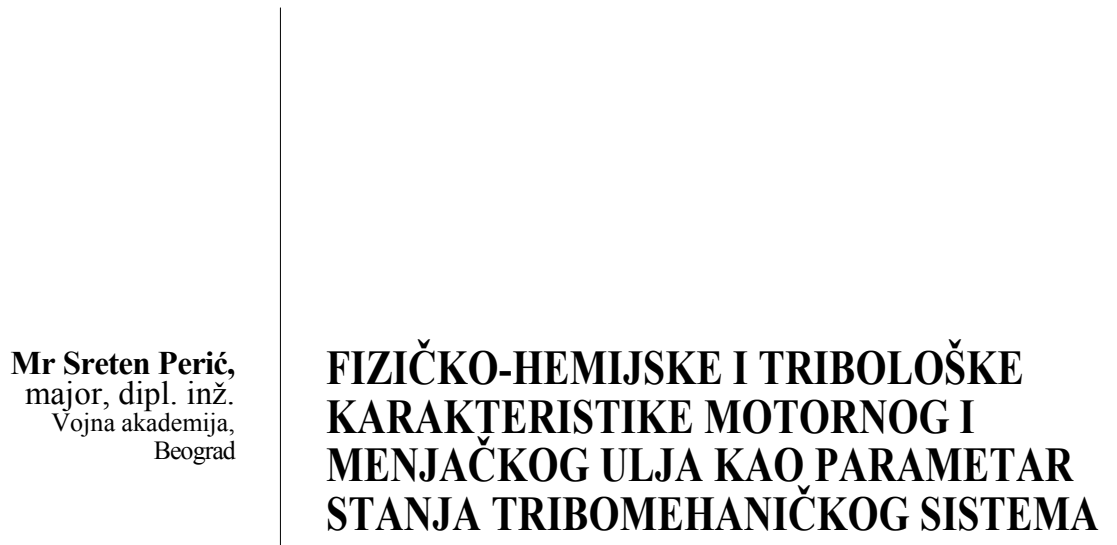

UDC: 621.892

Rezime:

Identifikacija stanja tribomehaničkih sistema bez narušavanja njegove funkcije, u uslovima gde se otkazi javljaju prvenstveno usled habanja elemenata i promene svojstava podmazujućeg sredstva, ima ogromne tehničke i ekonomske efekte. Sve prisutnija istraživanja na tribometrima objašnjavaju se nemogućnošću da se ispitivanjima realnih sistema obuhvati kompleksnost procesa trenja i habanja, kako po karakteru odvijanja fizičko-hemijskih procesa, tako i medusobnoj povezanosti velikog broja relevantnih parametara. Ispitivanje fizičkohemijskih $i$ triboloških karakteristika u funkciji utvrđivanja stanja tribomehaničkog sistema ima za cilj identifikaciju promena na elementima tog sistema. Odgovarajućim uzorkovanjima $i$ ispitivanjima u toku eksploatacije tribomehaničkog sistema, na osnovu prikazanog modela u radu, moguće je identifikovati stanje elemenata sistema i predvideti njegovo dalje ponašanje u eksploataciji, radi preventivnog održavanja.

Ključne reči: motorno ulje, menjačko ulje, tribologija, podmazivanje, tribomehanički sistem.

\title{
PHYSICOCHEMICAL AND TRIBOLOGICAL CHARACTERISTICS OF MOTOR OIL AND TRANSMISSION FLUID AS TRIBOMECHANICAL SYSTEM STATUS PARAMETERS
}

\section{Summary:}

The increasingly present investigations into tribometers can be explained by impossibility to embrace the complexity of the processes of friction and wear by investigating real systems, both by character of the physicochemical processes unfolding and mutual interrelations of a large number of influential parameters. The basic characteristics of examinations of tribometers are simplicity of their construction, low cost of conducting experiments, reduced experimenting time and a possibility to easily modify and control input variables. The application of tribology, and especially tribometry, regarding identification of the status of tribomechanical systems, aims to identify conditions and changes in processes and elements of tribomechanical systems. By adequate sampling and tribological investigations during tribomechanical system exploitation, on the basis of the model presented in this paper, it is possible to identify the status of a tribomechanical system and to predict its future behavior in exploitation, with purpose of preventive maintenance.

Key words: motor oil, transmission fluid, tribology, lubrication, tribomechanical system.

\section{Uvod}

Uslovi u kojima se nalaze elementi realnih tribomehaničkih sistema veoma su složeni i određeni su u velikoj meri karakteristikama maziva. Složenost uslo- va određena je temperaturom elemenata u kontaktu, temperaturom maziva, spoljašnjim opterećenjem, odnosno specifičnim pritiskom u zoni kontakta, dinamičkim karakterom ostvarivanja kontakta i prenosa snage i kretanja i dr. 
Vozilo kao tehničko sredstvo predstavlja skup veoma složenih tribomehaničkih sistema sastavljenih od niza podsistema koji predstavljaju, takođe, složene tribomehaničke sisteme. Čine ih svi sklopovi koji učestvuju u prenosu snage, odnosno obrtnog momenta od motora, preko sklopova transmisije (menjača, razvodnika pogona, diferencijala i ostalih sklopova), do izvršnih organa vozila.

Ulja za podmazivanje imaju niz osnovnih funkcija koje moraju izvršiti, a pored toga i jedan dodatni zadatak da, vršeći svoju funkciju, ne degradiraju ostale funkcije motora. Osnovne funkcije motornih ulja su:

- da podmazuju motor i smanjuju trenje i habanje njegovih pokretnih delova;

- da obezbeđuju dobro zaptivanje sklopa cilindar - klip;

- da štite motor od korozije; motora,

- da obezbeđuju efikasno hlađenje

- da održavaju motor u čistom i funkcionalnom stanju, sprečavaju stvaranje naslaga i nečistoća na delovima motora.
Ovako složene zadatke mogu ispuniti samo visokokvalitetna motorna ulja, koja moraju zadovoljiti sledeće uslove:

- zahtevanu viskoznost na niskim i visokim radnim temperaturama radi omogućavanja lakog hladnog starta i pravilnog podmazivanja motora u svim uslovima rada;

- visoku oksidacionu i termičku stabilnost, radi sprečavanja razlaganja ili stvaranja smola ulja pri visokim radnim temperaturama motora;

- dobro podnošenje visokih pritisaka radi sprečavanja povećanog habanja na kliznim površinama;

- dobre deterdžentno-disperzivne osobine radi sprečavanja većeg taloženja produkata sagorevanja na delovima motora i kanalima za podmazivanje, kao i stvaranja čvrstih taloga i lakova na klipovima, klipnim prstenovima i u prostoru za sagorevanje;

- dobru alkalnu rezervu radi neutralisanja kiselih produkata sagorevanja i u uslovima korišćenja goriva sa većim sadržajem sumpora.

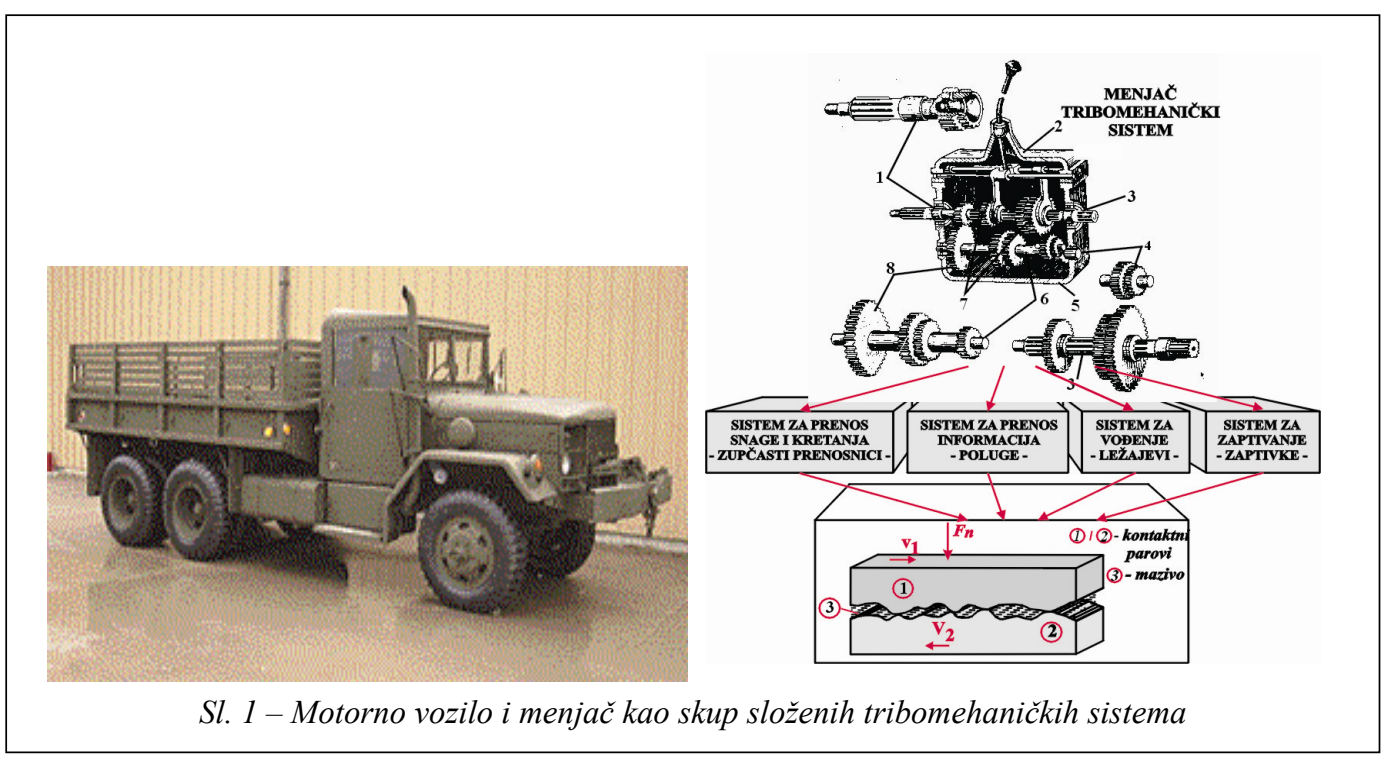


Kao primer složenog tribomehaničkog sistema može se navesti menjač vozila (slika 1). Ovaj sistem sastoji se od elemenata za prenos snage i kretanja (zupčanici i ožljebljena vratila), elemenata za prenos informacija (poluge), elemenata za vođenje (vođice) i zaptivanje (zaptivke).

Svaki od navedenih elemenata menjača može se dalje razložiti i analizirati kao skup posebnih tribomehaničkih sistema, kao što su zupčasti parovi, ležajevi i dr. Takođe, svaki zupčasti par se dalje može analizirati (posmatrati) kao pojedinačni elemenat koji ostvaruje kontakt. I, na kraju, svaki bok zuba zupčanika (ili kuglica kotrljajnog ležaja) može se posmatrati kao elementarna jedinica tribomehaničkog sistema.
Ova analiza ukazuje na činjenicu da se tribološke karakteristike jednog složenog tribomehaničkog sistema ne mogu posmatrati na jednostavan način i da nije moguće uspostaviti pouzdane metode i odrediti dijagnostičke parametre za ocenu stanja posmatranog sistema.

\section{Ispitivanje karakteristika ulja za podmazivanje}

Analizom veoma velikog broja otkaza složenih tribomehaničkih sistema može se zaključiti da je kod sistema kod kojeg je došlo do otkaza, takođe i kod maziva (odnosno ulja za podmazivanje), došlo do određenih promena. Naime, otkaz tribomehaničkog sistema može nastupiti usled promene svojstava ulja za

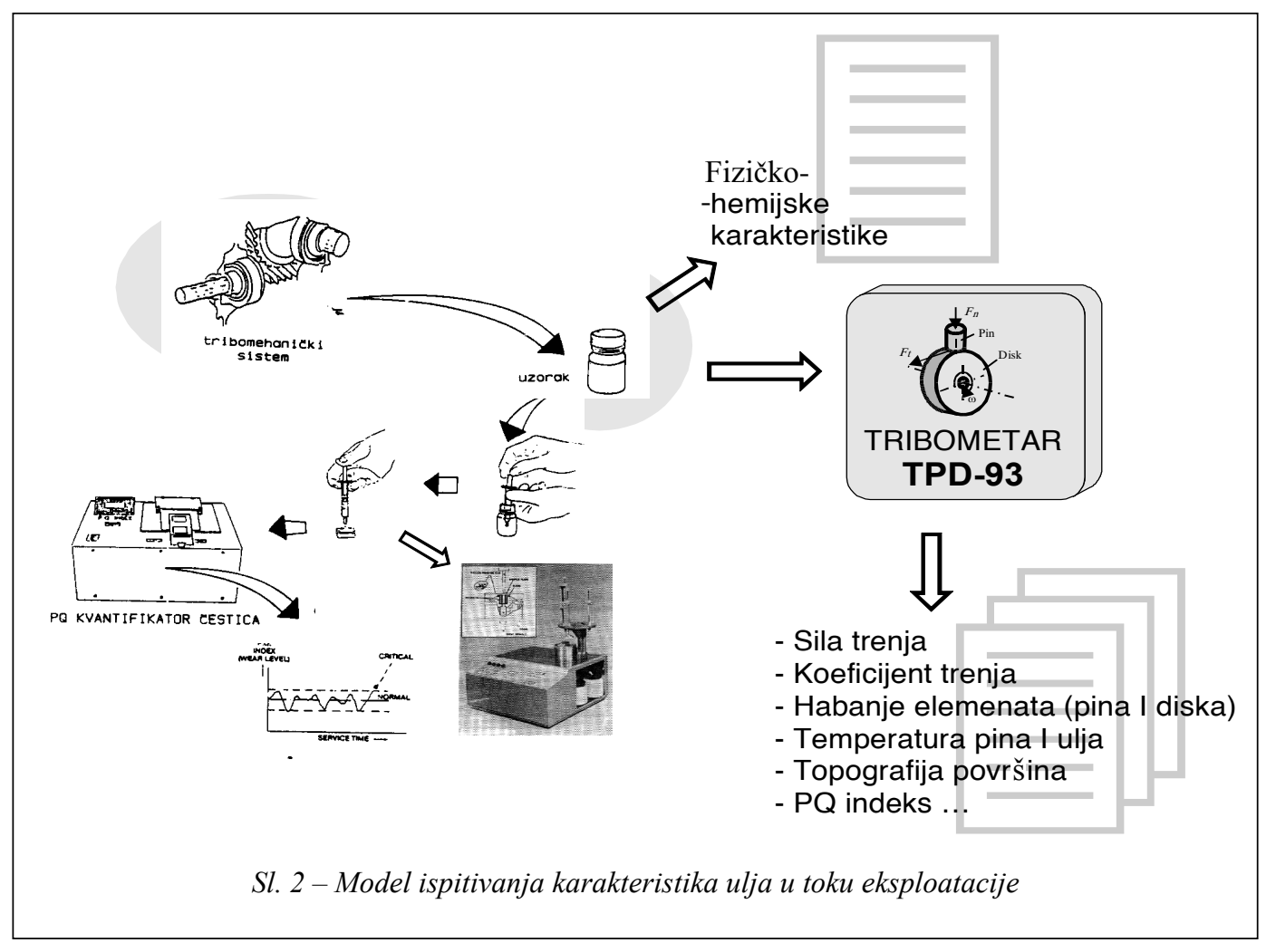


podmazivanje. Takođe, do promene karakteristika ulja za podmazivanje može doći usled otkaza pojedinih ostalih elemenata tribomehaničkog sistema.

Kako se u najvećem broju slučajeva promena funkcionalnosti složenog tribomehaničkog sistema ogleda u promenama karakteristika ulja za podmazivanje, to se promena fizičko-hemijskih i triboloških karakteristika ulja može usvojiti kao parametar za ocenu stanja tribomehaničkog sistema.

Radi razvoja modela za identifikaciju stanja tribomehaničkog sistema, analizom ulja za podmazivanje, poslednjih godina odvijaju se mnogobrojna eksperimentalna ispitivanja u laboratorijama VTI Žarkovo i Mašinskog fakulteta u Kragujevcu. Cilj ispitivanja je verifikacija modela koja podrazumeva povremeno uzorkovanje ulja za podmazivanje iz realnih tribomehaničkih sistema i analiza njegovih fizičko-hemijskih i triboloških karakteristika u toku eksploatacije. Na slici 2 prikazana je šema funkcionisanja modela.

\section{Fizičko-hemijske karakteristike mazivih ulja}

Osnovne fizičko-hemijske osobine pomoću kojih se određuje kvalitet ulja su:

- fizičke osobine: viskoznost, indeks viskoznosti, temperatura paljenja, temperatura stišnjavanja, gustina, specifična toplota, penušanje i dr.;

- hemijske osobine: hemijska i termička stabilnost, korozivnost, neutralizacioni broj, ukupan bazni broj, kompatibilnost, toksičnost i dr.

U okviru ovog dela rada prikazan je deo rezultata obimnih eksperimentalnih ispitivanja različitih ulja (motornih i drugih) u Laboratoriji za pogonska sredstva VTI Žarkovo, Beograd.
Ispitivanjima su mereni: viskoznost ulja za različite namene (slika 3), indeks viskoznosti (slika 4), gustina (slika 5), temperatura paljenja (slika 6), temperatura stišnjavanja (slika 7), penušanje (slika 8), ukupan bazni broj (slika 9) i toksičnost.

Na slici 3 prikazana je promena veličine merenih vrednosti viskoznosti $u$ zavisnosti od vrste ulja. Ulja namenjena za hladnije uslove $(10 \mathrm{~W}, 15 \mathrm{~W}, \ldots)$ imaju manju viskoznost od ulja namenjenih za toplije klimatske uslove.

Na slici 8 prikazano je kako u novijim uljima koja imaju više aditiva raste baznost. Tako ulje 15W-40 CE ima više aditiva od ulja 15W-40 SF-CC, jer je savremenije, pa samim tim ima i veći ukupni bazni broj - TBN. Kada vrednost ukupnog baznog broja padne ispod određene vrednosti ulje treba zameniti.

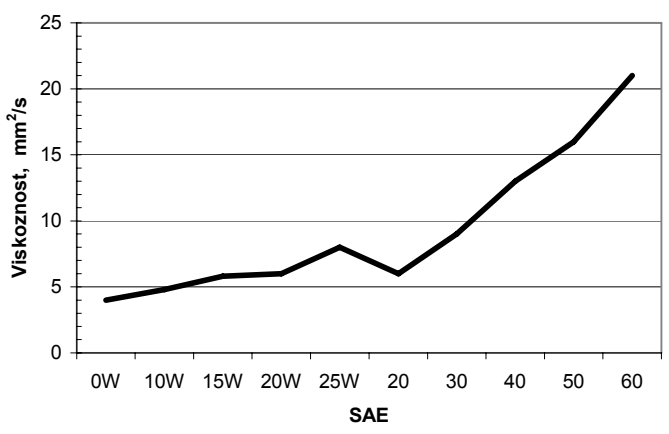

Sl. 3 - Promena viskoznosti u zavisnosti od vrste ulja

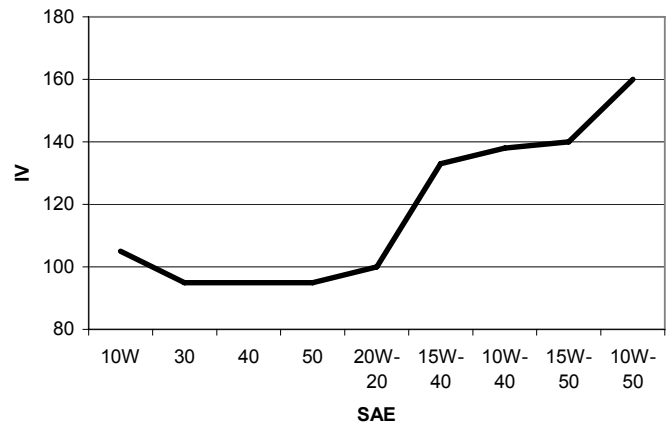

Sl. 4 - Promena indeksa viskoznosti u zavisnosti od vrste ulja 


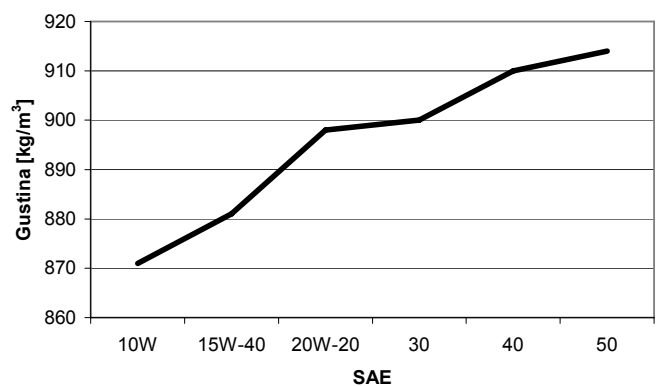

Sl. 5 - Gustina ulja na $288,15 \mathrm{~K}$ za različite vrste ulja

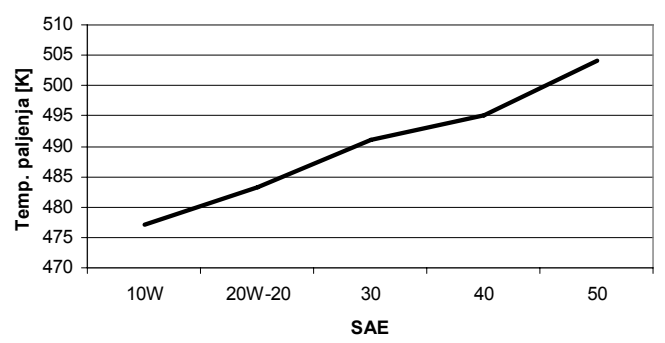

Sl. 6-Temperature paljenja za neke vrste ulja

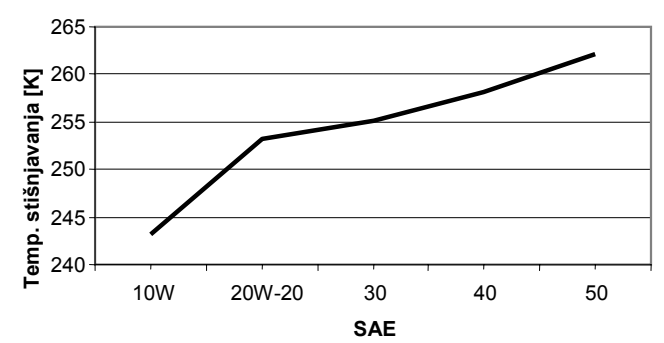

Sl. 7 - Temperature stišnjavanja za neke karakteristične vrste ulja

Vrednosti sa kojima se upoređuju rezultati ispitivanja sklonosti stvaranja i stabilnosti pene

\begin{tabular}{|c|c|c|}
\hline & $\begin{array}{c}\text { Sklonost stvaranja } \\
\text { pene }\end{array}$ & Stabilnost pene \\
\cline { 2 - 3 } & $\begin{array}{c}\text { Zapremina } 1 \mathrm{~cm}^{3}, \\
\text { nakon } 5 \mathrm{~min} \\
\text { produvavanja }\end{array}$ & $\begin{array}{c}\text { Zapremina } 1 \mathrm{~cm}^{3}, \\
\text { nakon 10 min stajanja }\end{array}$ \\
\hline $\begin{array}{c}297,15 \mathrm{~K} \\
\left(24^{\circ} \mathrm{S}\right)\end{array}$ & $2 \mathrm{~cm}^{3}$ & $0 \mathrm{~cm}^{3}$ \\
\hline $\begin{array}{c}366,65 \mathrm{~K} \\
\left(93,5^{\circ} \mathrm{S}\right)\end{array}$ & $150 \mathrm{~cm}^{3}$ & $0 \mathrm{~cm}^{3}$ \\
\hline $\begin{array}{c}297,15 \mathrm{~K} \\
\left(24^{\circ} \mathrm{S}\right) \text { nakon } \\
\begin{array}{c}366,65 \mathrm{~K} \\
\left(93,5^{\circ} \mathrm{S}\right)\end{array}\end{array}$ & $0 \mathrm{~cm}^{3}$ & $0 \mathrm{~cm}^{3}$ \\
\hline
\end{tabular}

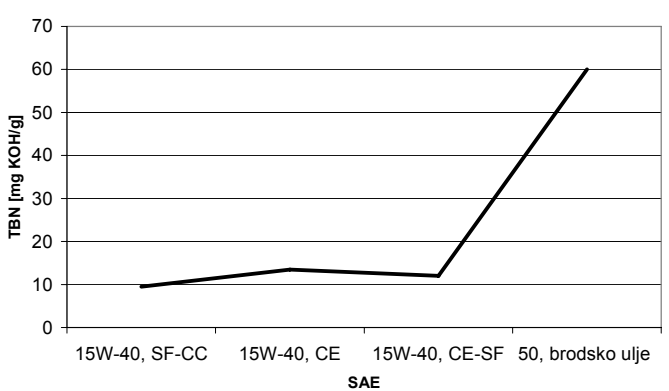

Sl. 8 - Prikaz baznosti u jednoj vrsti ulja različitog kvaliteta

Toksičnost označava sve aspekte uticaja ulja za podmazivanje na zdravlje ljudi, biljni i životinjski svet. Toksičnost mineralnih ulja je mala, dok su sa sintetskim uljima osnovni problemi vezani za delovanje na ljudsku kožu. Međutim, ulja koja sadrže različite hemijske supstance (aditive) mogu biti uzročnik mnogih oboljenja.

\section{Rezultati ispitivanja promene karakteristika motornih ulja tokom eksploatacije}

U okviru ovog dela rada prikazani su rezultati dela eksperimentalnih ispitivanja motornih ulja u Laboratoriji za pogonska sredstva. Ispitivanje je izvršeno na vozilu u koje je ugrađen motor Mercedes-Benz EURO 2 OM 906 hLA. To je dizel motor savremene konstrukcije, koji ispunjava EURO 2 norme vezane za emisiju izduvnih gasova. Uzorkovanje i ispitivanje motornog ulja je vršeno $u$ toku pređenih 17200 kilometara.

Na slici 9 prikazana je promena viskoznosti u toku ispitivanja. Vidljiv je pad viskoznosti tokom pređenih prvih $5000 \mathrm{~km}$, a nakon ovog perioda viskoznost ostaje približno konstantna do kraja intervala izmene uljnog punjenja. 


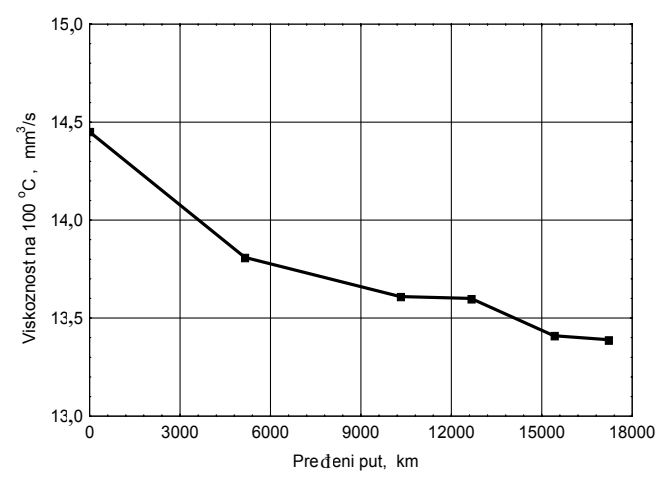

Sl. 9 - Promena viskoznosti motornog ulja tokom eksploatacije

Na slici 10 prikazana je promena totalnog baznog broja (TBN). Totalni bazni broj predstavlja meru alkalnosti motornog ulja, tj. sposobnosti detergentnih ulja za neutralizacijom kiselih materija i zaštita motora pre i posle eksploatacije. Izražava se u količini miligrama kalijum-hidroksida potrebnih za neutralizaciju prisutnih slobodnih kiselina u jednom gramu ulja.

Do pređenih $15000 \mathrm{~km}$ vrednost TBN-a nije prekoračila dozvoljene granice. Daljnjim korišćenjem motornog ulja pad vrednosti $\mathrm{TBN}$-a bio je $57,85 \%$, što je iznad dozvoljene granice od 50\%. Posle pređenih $17000 \mathrm{~km}$ ulje je zamenjeno, isključivo usled pada vrednosti TBN-a. Pad vrednosti TBN-a je, najverovatnije, posledica lošeg kvaliteta goriva (visok sadržaj sumpora) i brže degradacije ulja nakon pređenih $15000 \mathrm{~km}$, a može biti uzrokovan i nepotpunim sagorevanjem.

Na slici 11 prikazane su promene gustine motornog ulja tokom eksploatacije. Promena gustine je vrlo slabo izražena tokom celog perioda eksploatacije. Inače, porast gustine mineralnih ulja je u funkciji povećanja molekulske mase, zavisno od preovlađujućeg sadržaja određene vrste ugljovodonika. Na intenzivniji porast gustine utiče prisustvo sumpornih spojeva.

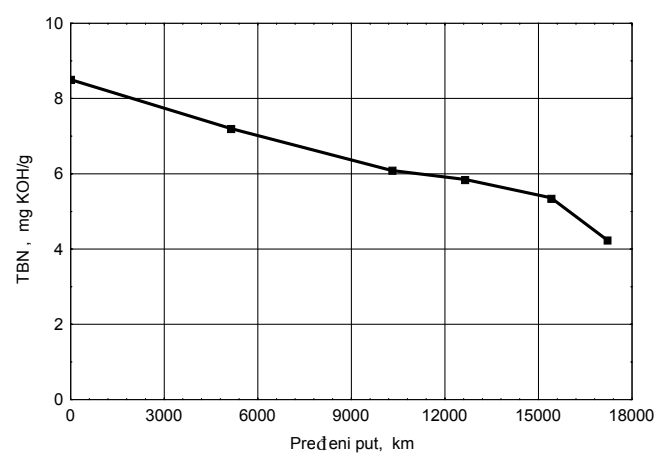

Sl. 10 - Promena TBN-a motornog ulja tokom eksploatacije

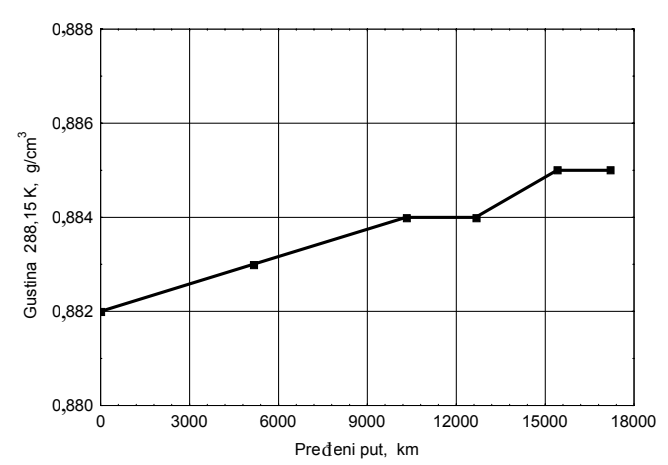

Sl. 11 - Promena gustine motornog ulja tokom eksploatacije

Sadržaj nerastvorenih materija $u$ ulju je zanemarljiv u odnosu na dozvoljene vrednosti odstupanja (maksimalno nerastvorno u pentanu $0,29 \%$, a dozvoljeno je do 3,5\%; maksimalno nerastvorno u benzenu $0,35 \%$, dozvoljeno je do $2,5 \%$ ). Promene vrednosti nerastvornih materija u pentanu i benzenu grafički su prikazane na slikama 12 i 13 .

Određivanje sadržaja gvožđa (slika 14) ukazuje na to da se habanje u tribomehaničkim sklopovima motora nalazi u okviru dozvoljenih granica, što pokazuje sadržaj gvožđa u ulju. 


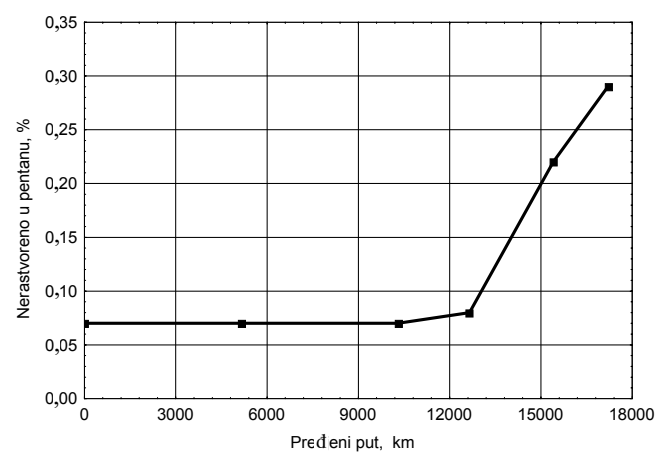

Sl. 12 - Promena vrednosti nerastvorenih materija u pentanu tokom eksploatacije ulja

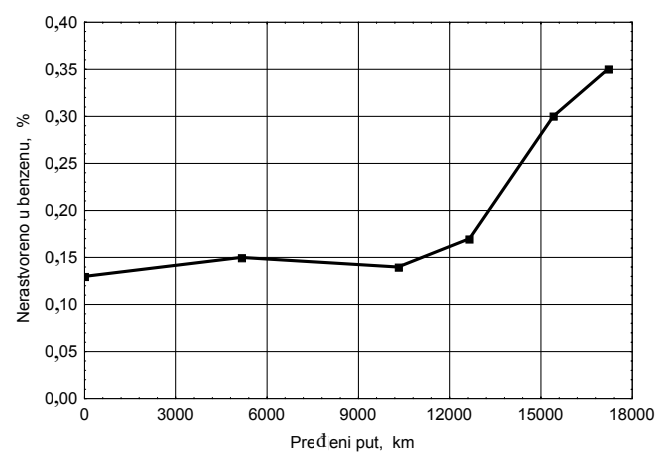

Sl. 13 - Promena vrednosti nerastvorenih materija u benzenu tokom eksploatacije ulja

U uzorcima nije bilo pojave vode. Voda je nepoželjni kontaminat u ulju, koja zbog prenosa kiseonika iz vazduha ubrzava starenje ulja. Veće količine menjaju boju ulja u boju bele kafe do bele boje, a za više desetina procenata vode nastaje emulzija vode i ulja koja prelazi u pihtijastu masu.

Tačka paljenja je podatak koji pokazuje pri kojoj temperaturi dolazi do paljenja otvorenim plamenom pare koja se stvara zagrevanjem ulja i bitna je u pogledu sigurnosti u toku eksploatacije motora SUS. Najveći pad vrednosti tačke paljenja je $14 \mathrm{~K}$, što je mnogo ispod dozvoljenih $20 \%$, a ukazuje na to da nije došlo do značajnijeg prodora goriva u sistem za podmazivanje (sistem za napajanje gorivom je ispravan i motor je $\mathrm{u}$ dosta dobrom stanju).

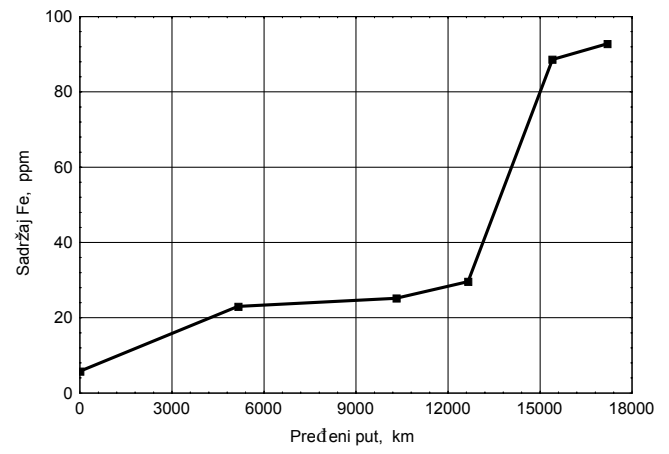

Sl. 14 - Promena sadržaja gvožđa u motornom ulju tokom eksploatacije

\section{Tribološke karakteristike}

Tribomehanički sistem definisan je kontaktom dva elementa, dok je treći elemenat mazivo. Proces se dešava u nekoj sredini. U okviru ovih ispitivanja posebno su interesantni uslovi kontakta elemenata kod sklopova motora ili transmisije vozila. Da bi se realno posmatrali uslovi i realizovala tribološka istraživanja moraju se imati u vidu sledeći elementi u kojima funkcioniše tribomehanički sistem: vrsta kretanja (klizanje, kotrljanje i dr.), brzina relativnog kretanja, vrsta kontakta (u tački, po liniji, po površini i dr.), normalno opterećenje, temperatura sredine i vreme ostvarivanja kontakta, hrapavost i sastav površinskog sloja.

Tribološke karakteristike kojima se opisuju elementi u kontaktu su: sila trenja, koeficijent trenja, buka, vibracije, porast temperature, intenzitet habanja $\mathrm{i}$ debljina sloja maziva, učešće produkata habanja u mazivu, itd. 


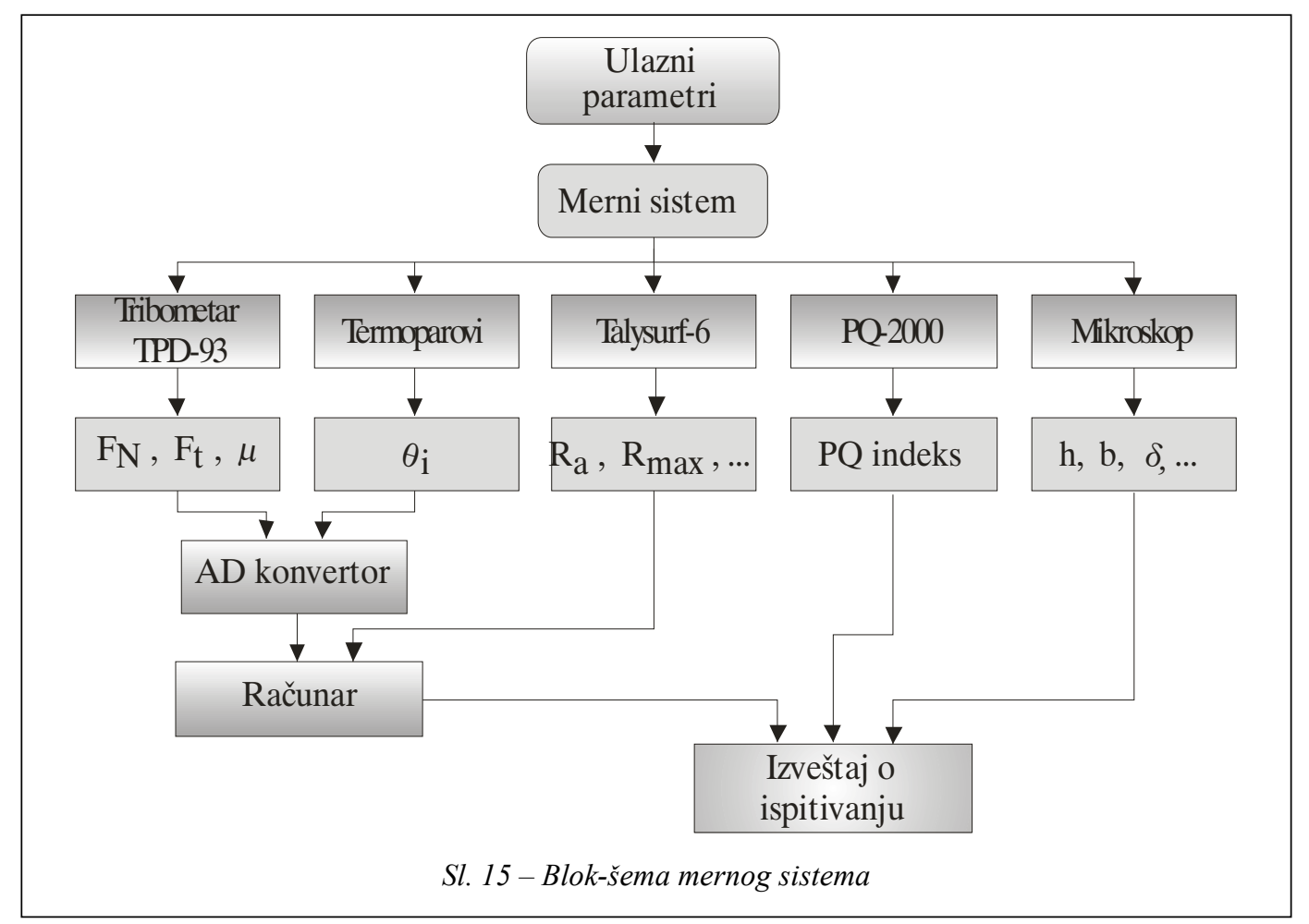

$\mathrm{Na}$ slici 15 prikazana je blok-šema najčešće korišćenog mernog lanca za ispitivanje triboloških karakteristika maziva, realizovan na Mašinskom fakultetu u Kragujevcu.

Na slici 16 prikazan je najčešće korišćeni merni lanac za ispitivanje triboloških karakteristika maziva, realizovan na Mašinskom fakultetu u Kragujevcu.

Na slici 17 prikazan je razmatrani tribomehanički sistem sa ulaznim i izlaznim parametrima.

Razvojem teorijskih postavki procesa habanja materijala razvijale su se i eksperimentalne metode za ispitivanje triboloških karakteristika. Ova ispitivanja spadaju u grupu laboratorijskih ispitivanja koja se obavljaju na specijalno konstruisanim uređajima tribometrima.
Ova ispitivanja najčešće se vrše zbog sledećih razloga:

- određivanje zavisnosti između otpornosti na habanje i fizičko-hemijskih i mehaničkih svojstava materijala $u$ kontaktu sa ciljem proizvodnje materijala (elemenata u kontaktu ili maziva) sa unapred zadatim tribološkim svojstvima,

- utvrđivanje zakonitosti habanja materijala $\mathrm{u}$ funkciji radnih parametara (opterećenja, brzine klizanja), kao i radnih uslova (temperature, topografije i dr.),

- izbor optimalnih konstruktivnih i mazivih materijala i određivanje njihove međuzavisnosti.

Cilj ispitivanja u novije vreme je uspostavljanje korelacija rezultata ispitivanja fizičko-hemijskih karakteristika sa tribološkim karakteristikama za konkretna sredstva u eksploataciji. 

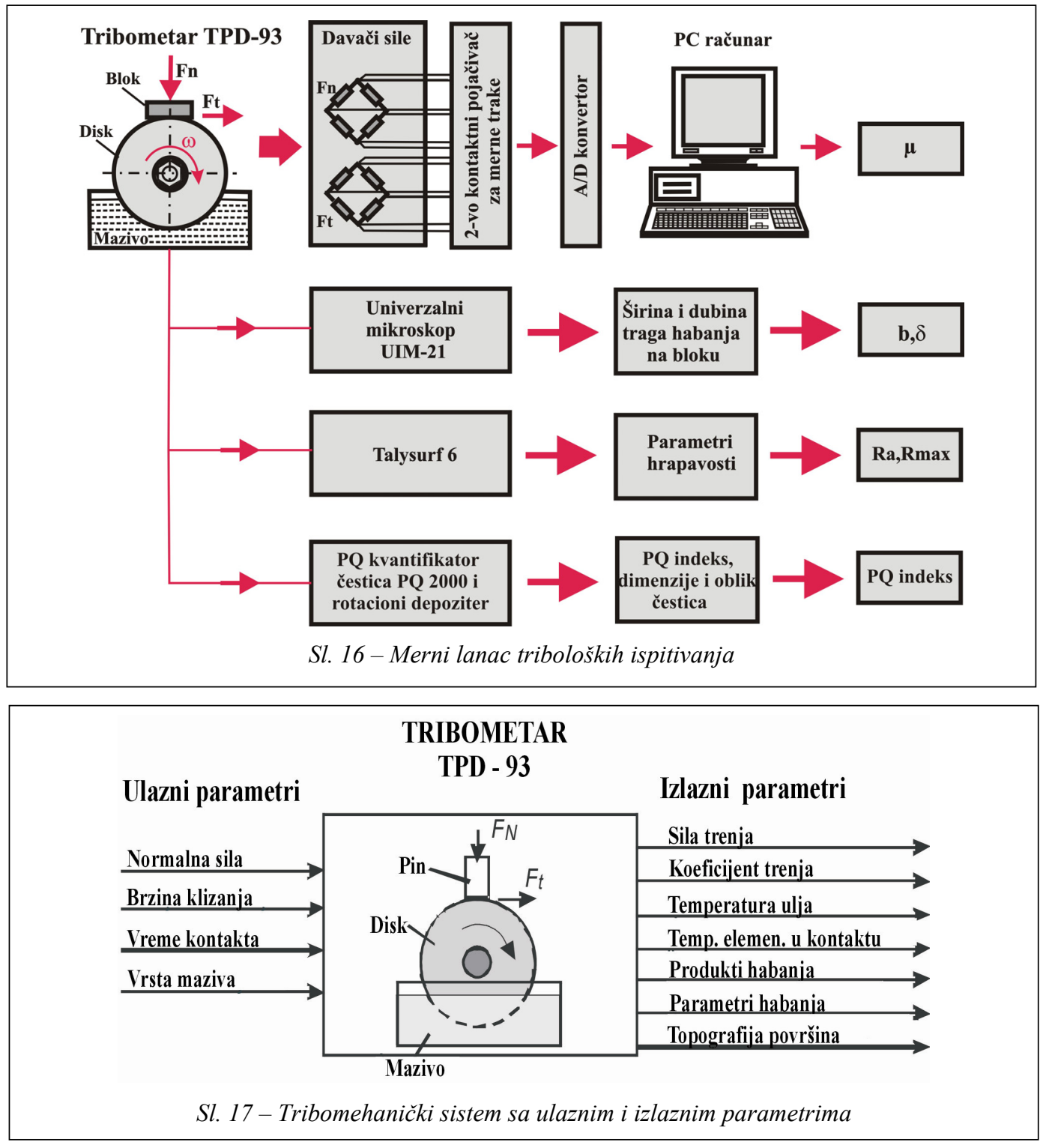

Realizovana ispitivanja, pri čemu je vršeno uzorkovanje ulja iz menjača vozila Vojske: TAM 2001, TAM T110 i TAM T130 koja su bila u eksploataciji, i odgovarajuća tribološka merenja na tribometru TPD-93, potvrdila su mogućnost identifikacije promena karakteristika elemenata menjača kao složenog tribomehaničkog sistema.
$\mathrm{Na}$ osnovu realizovanih ispitivanja dobijeni su odgovarajući histogrami promene koeficijenta trenja mereni nakon određenog vremena ostvarivanja kontakta na tribometru u zavisnosti od uzorka ulja, odnosno pređenog puta vozila, PQ indeksa i širine pojasa habanja PINa.

Na slikama 18, 19 i 20 prikazan je samo deo rezultata ispitivanja nekih ulja 
za podmazivanje menjača vozila. Pri ovim ispitivanjima korišćeno je ulje iz realnih sistema, odnosno iz motornih vozila koja su aktivno bila u upotrebi i prelazila određeni broj kilometara puta do uzimanja uzorka ulja.

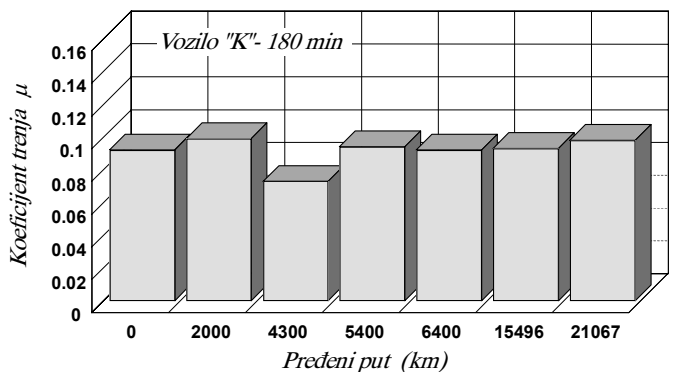

Sl. 18 - Koeficijent trenja meren nakon 180 min u zavisnosti od pređenog puta vozila

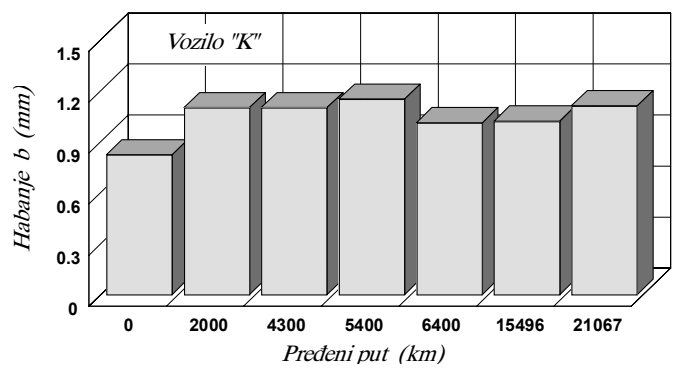

Sl. 19 - Zavisnost širine traga habanja b pina od pređenog puta vozila

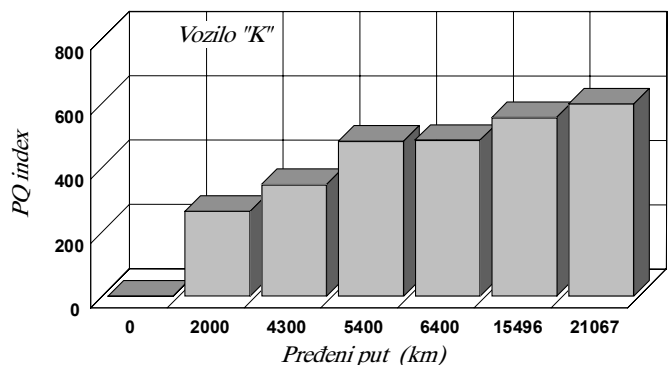

Sl. 20 - Zavisnost PQ indeksa od pređenog puta vozila

\section{Zaključak}

Razvijenom metodologijom ispitivanja, uz korišćenje opisane opreme, pokazano je da se ispitivanja u laboratorijskim uslovima mogu koristiti za identifikaciju karakteristika i stanja elemenata tribomehaničkih sistema. Ovakav pristup izučavanju triboloških procesa daje znatne prednosti u odnosu na ispitivanja u realnim uslovima. Međutim, može se primeniti u uslovima kada uzorkovanje ne remeti funkcionisanje realnog sistema. U ovom slučaju, to je uzorkovanje ulja za podmazivanje. Pomoću primenjenog metoda ispitivanja konstatovano je da dolazi do promena fizičko-hemijskih i triboloških karakteristika ulja za podmazivanje u motoru i menjaču stepena prenosa vozila. Ove promene su u direktnoj zavisnosti od stanja svih elemenata tribomehaničkog sistema, odnosno $\mathrm{u}$ zavisnosti od njihovih funkcionalnih karakteristika.

\section{Literatura:}

[1] Ivković, B., Rac, A.: Tribologija, Jugoslovensko društvo za tribologiju, Kragujevac, 1995.

[2] Rac, A.: Osnovi tribologije, Mašinski fakultet, Beograd.

[3] Pešić, Z., Nedić, B.: Razvoj modela za identifikaciju promena triboloških karakteristika ulja za podmazivanje menjača vozila, YUMO '98, Mašinski fakultet, Kragujevac, 1998.

[4] Pešić, Z.: Identifikacija triboloških procesa u menjaču vozila sa aspekta optimalnog održavanja, doktorska disertacija u rukopisu, Mašinski fakultet, Kragujevac, 1998.

[5] Pešić, Z., Perić, S., Krsmanović, M.: Promena fizičko hemijskih karakteristika motornog ulja tokom eksploatacija sa aspekta dijagnostike stanja, Yutrib 05. Kragujevac 2005. 


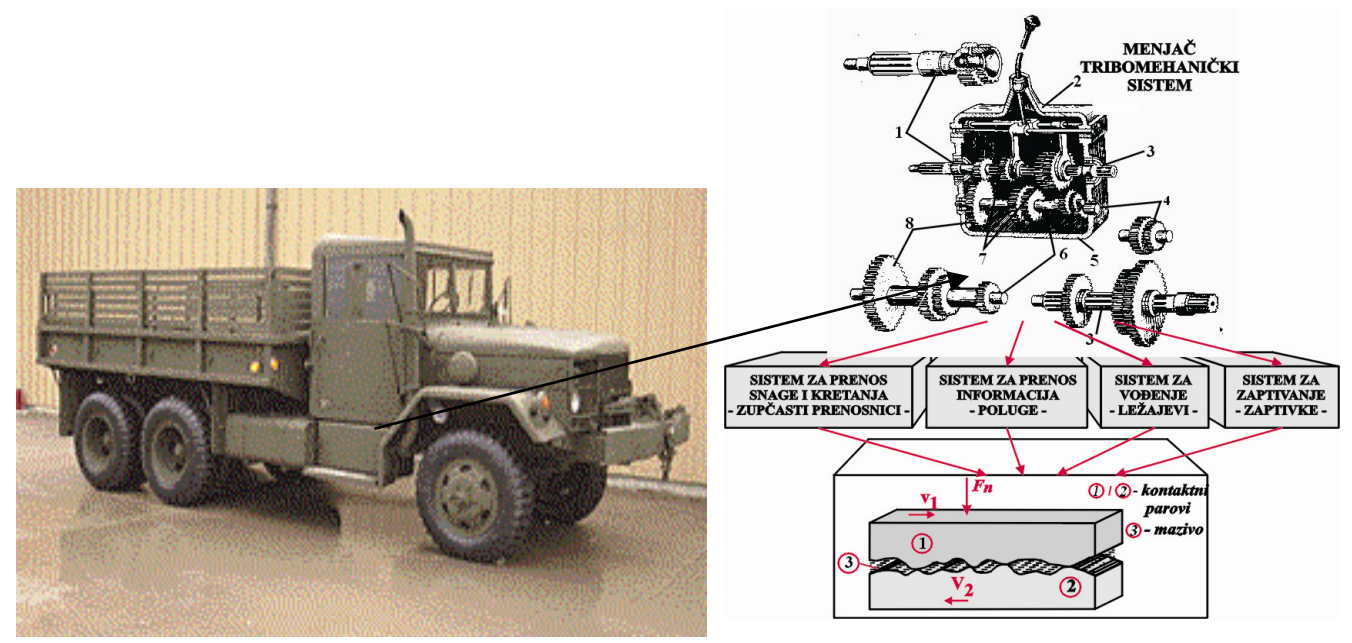

Sl. 1 - Motorno vozilo i menjač kao skup složenih tribomehaničkih sistema

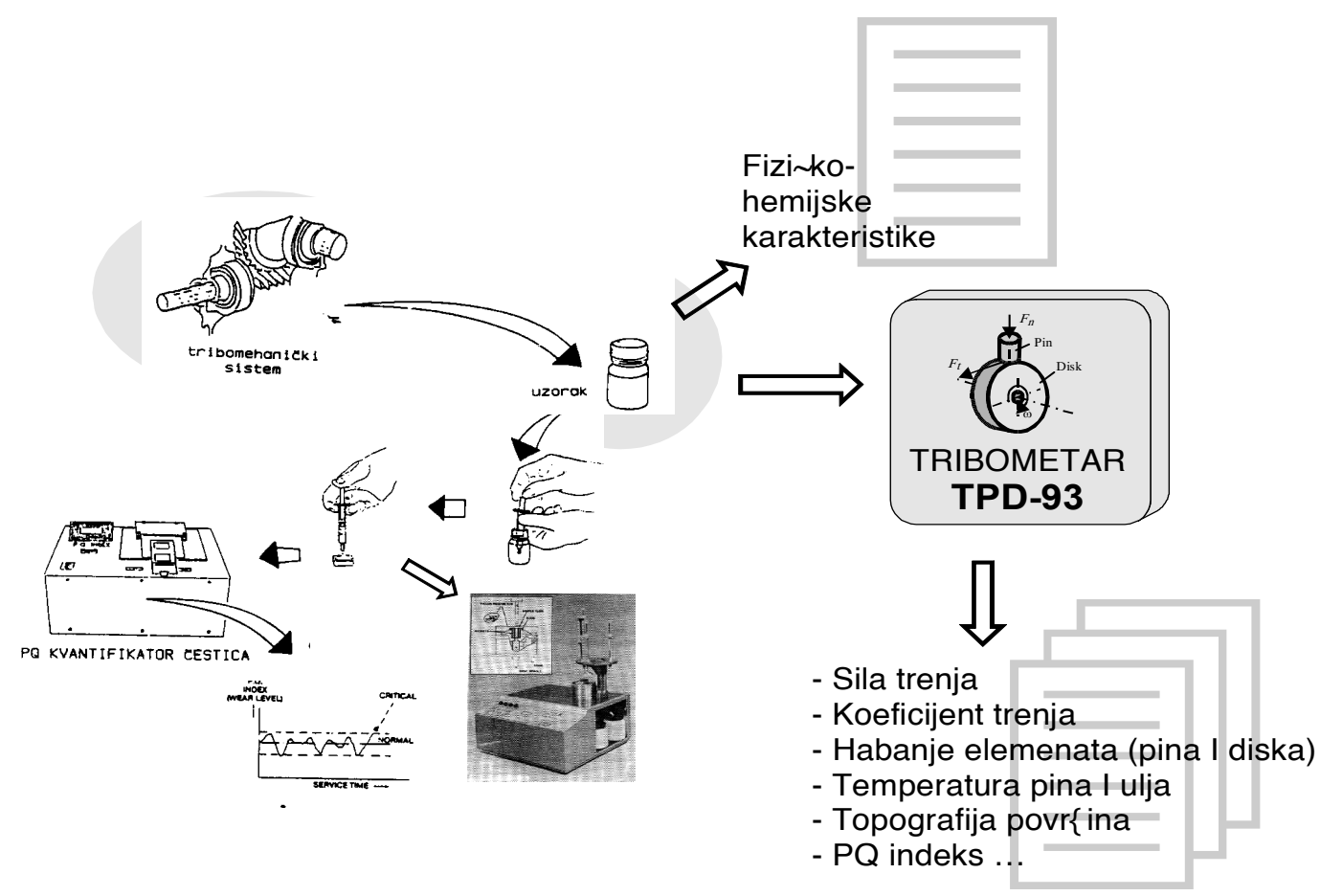

Sl. 2 - Model ispitivanja karakteristika ulja u toku eksploatacije 


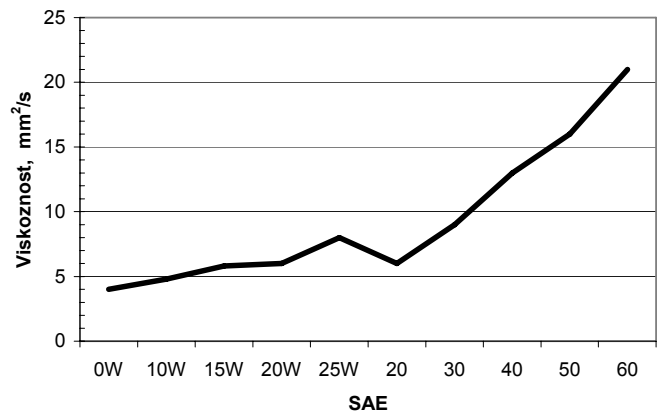

Sl. 3 - Promena viskoznosti u zavisnosti od vrste ulja

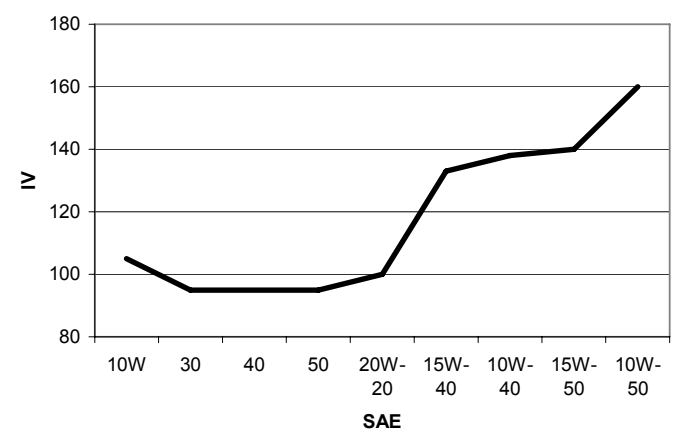

Sl. 4 - Promena indeksa viskoznosti u zavisnosti od vrste ulja

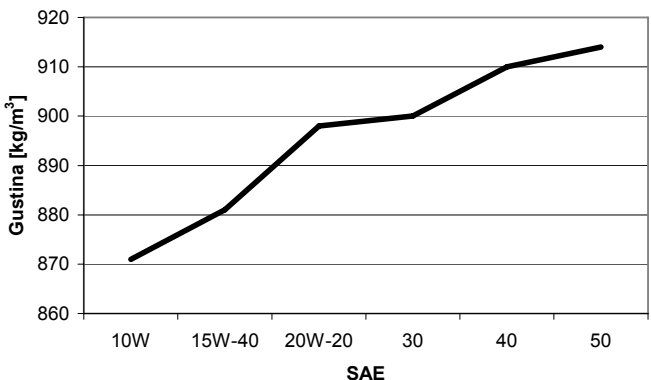

Sl. 5 - Gustina ulja na 288,15 K za različite vrste ulja

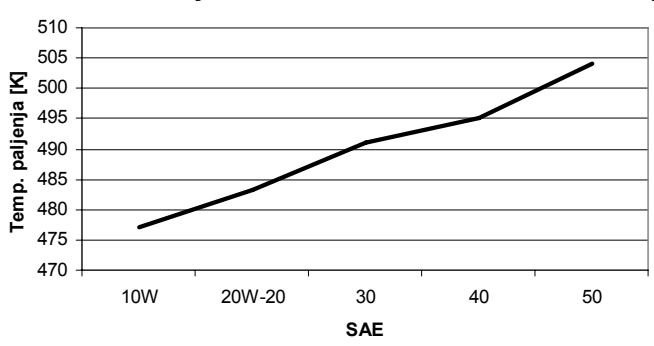

Sl. 6 - Temperature paljenja za neke vrste ulja 


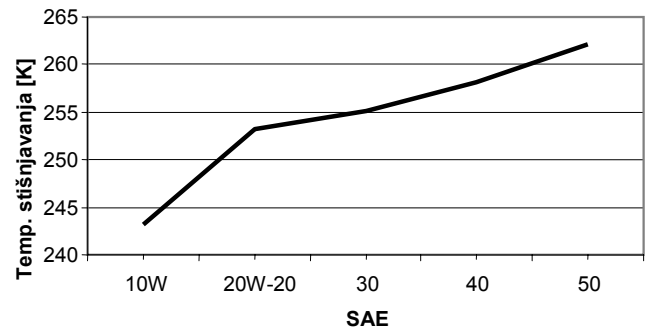

Sl. 7 - Temperature stišnjavanja za neke karakteristične vrste ulja

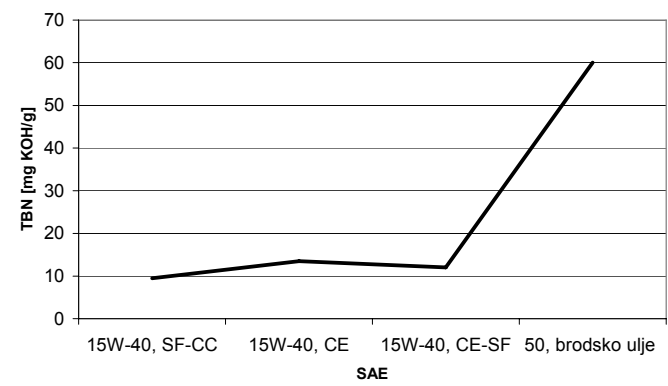

Sl. 8 - Prikaz baznosti u jednoj vrsti ulja različitog kvaliteta

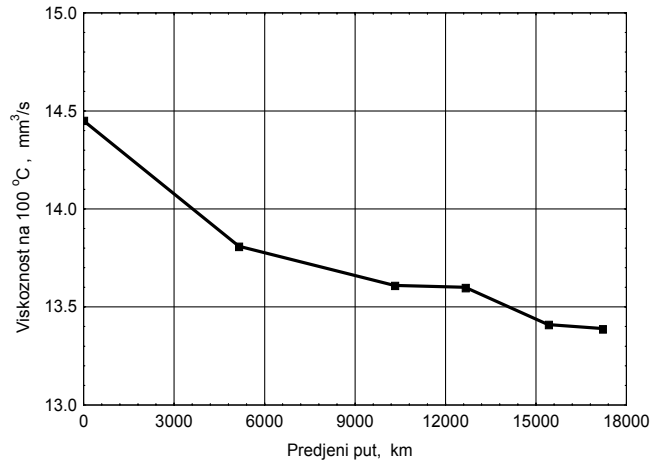

Sl. 9 - Promena viskoznosti motornog ulja tokom eksploatacije 


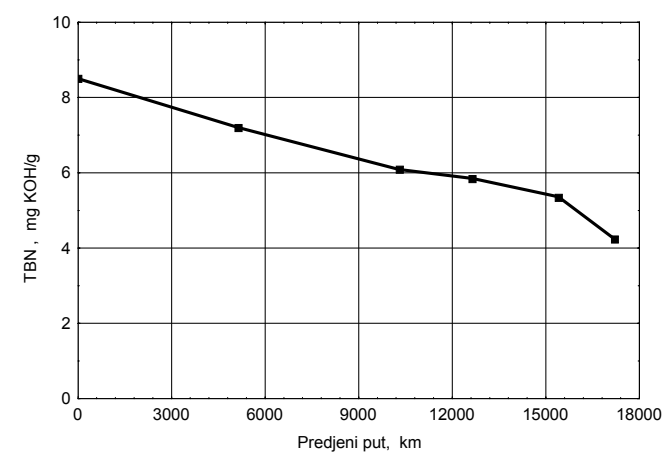

Sl. 10 - Promena TBN-a motornog ulja tokom eksploatacije

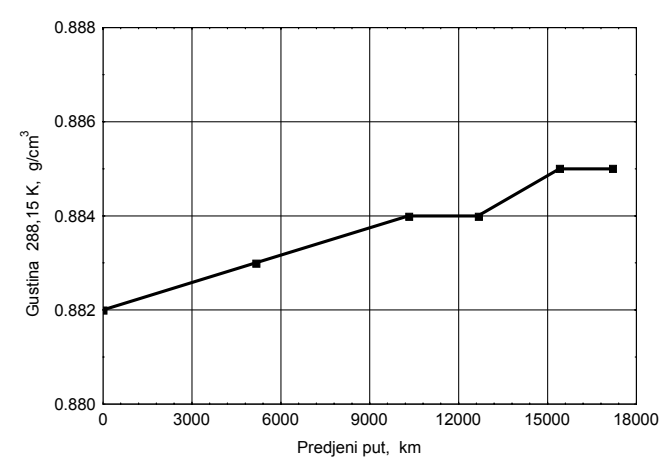

Sl. 11 - Promena gustine motornog ulja tokom eksploatacije

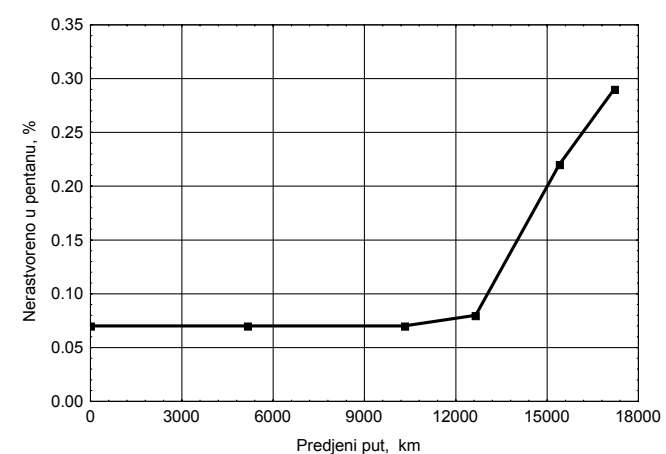

Sl. 12 - Promena vrednosti nerastvorenih materija u pentanu tokom eksploatacije ulja 


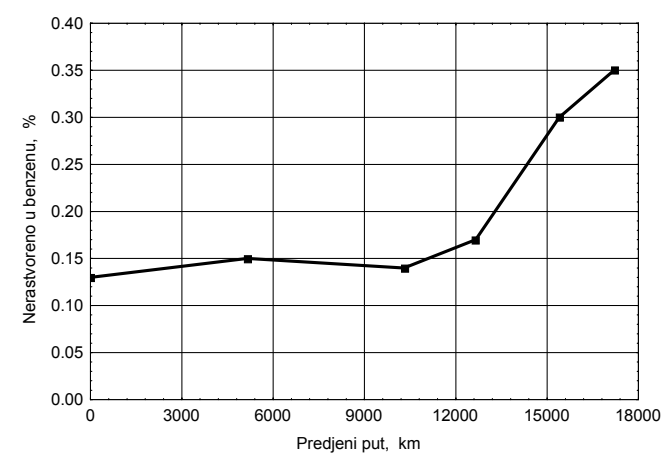

Sl. 13 - Promena vrednosti nerastvorenih materija u benzenu tokom eksploatacije ulja

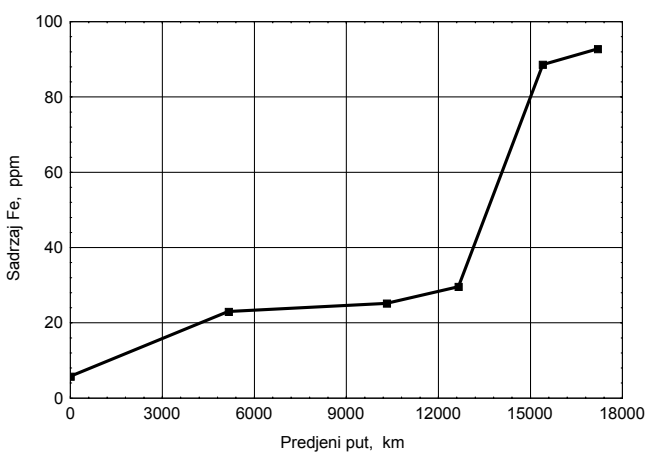

Sl. 14 - Promena sadržaja gvožđa u motornom ulju tokom eksploatacije 


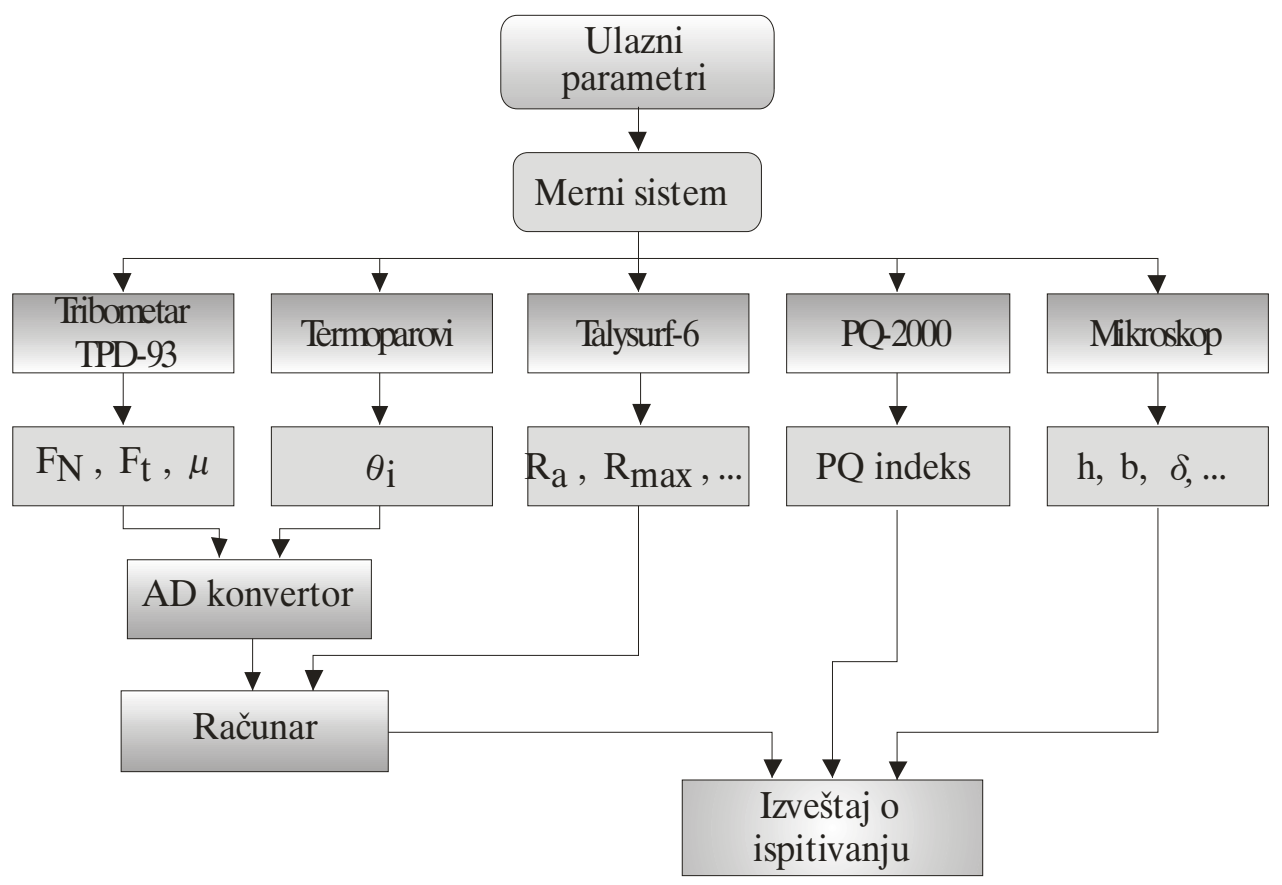

Sl. 15 - Blok-šema mernog sistema

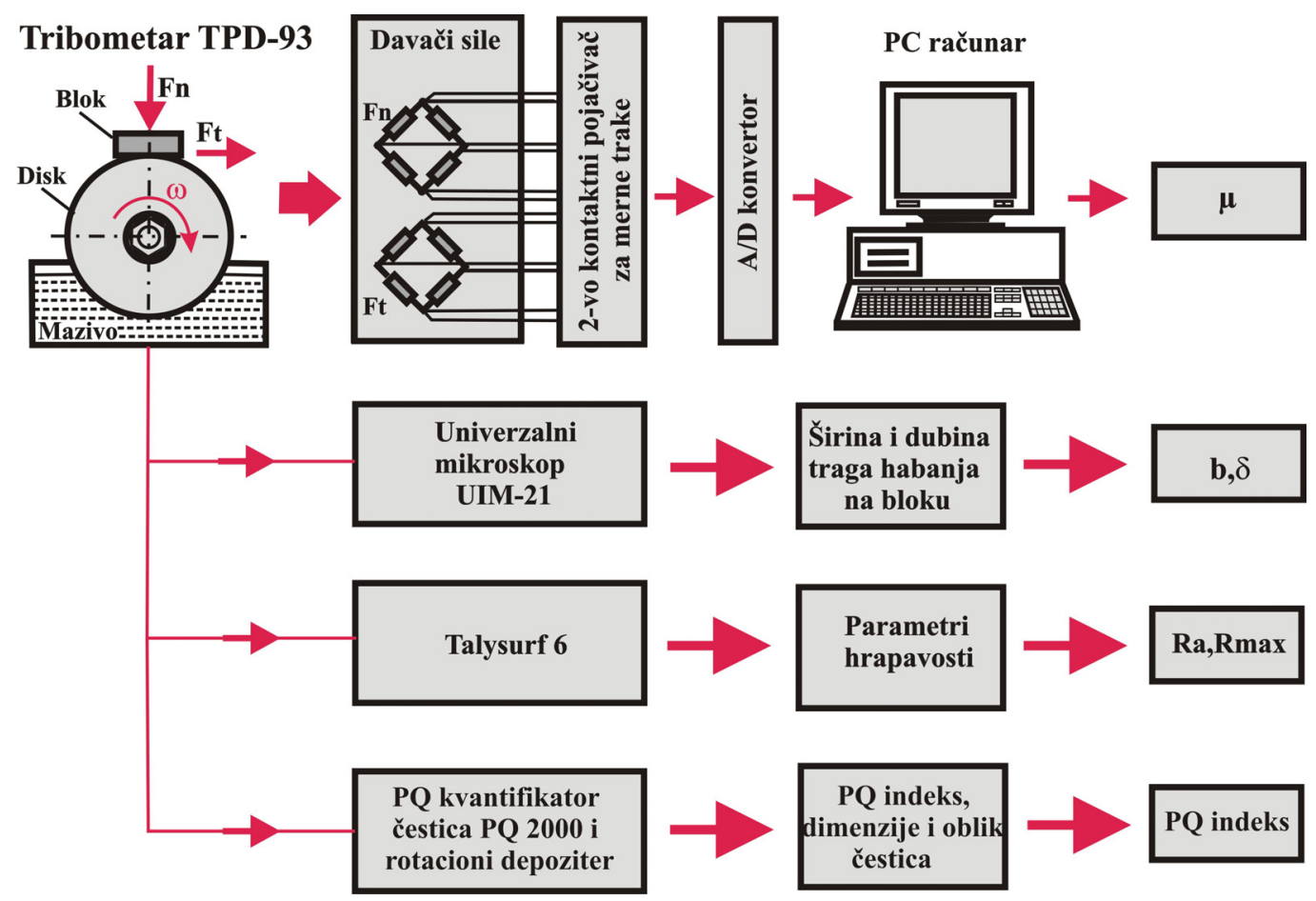




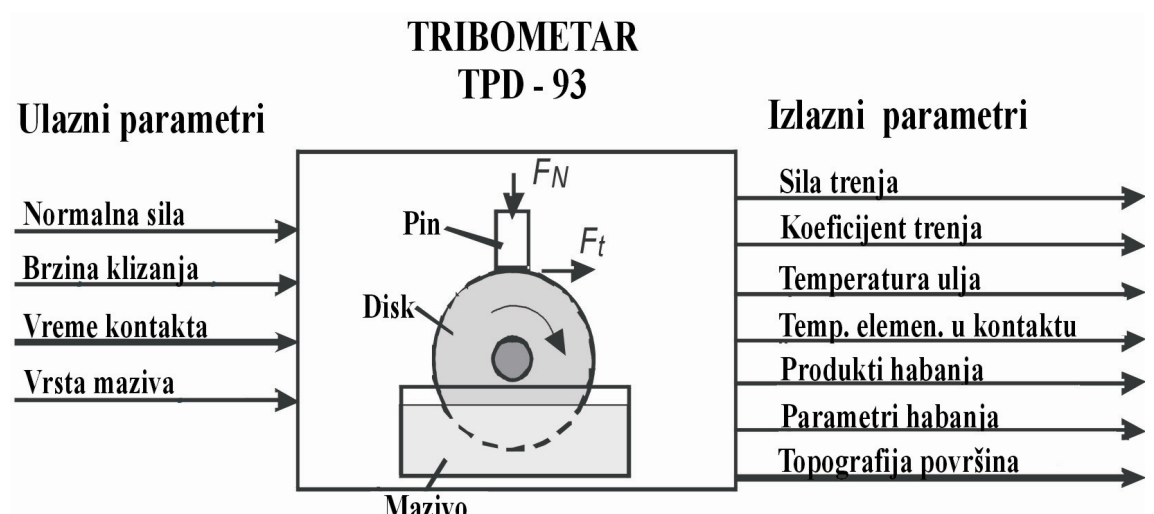

Sl. 17 - Tribomehanički sistem sa ulaznim i izlaznim parametrima

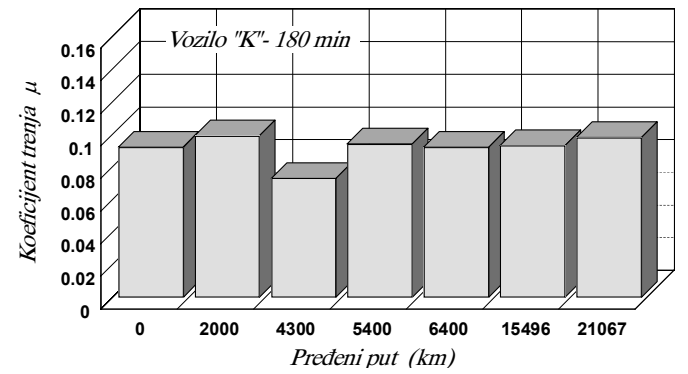

Sl. 18 - Koeficijent trenja meren nakon 180 min u zavisnosti od pređenog puta vozila

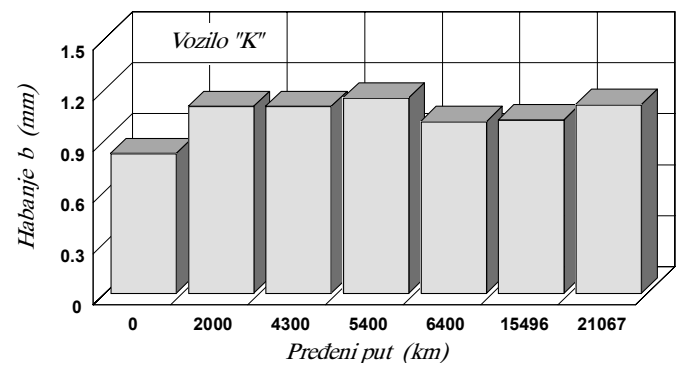

Sl. 19 - Zavisnost širine traga habanja b pina od pređenog puta vozila 


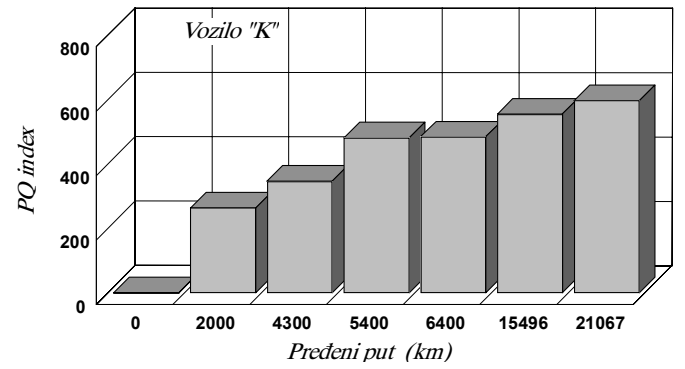

Sl. 20 - Zavisnost PQ indeksa od pređenog puta vozila 